\title{
SER BABÁ DO OUTRO LADO DO OCEANO: CUIDAR DOS FILHOS DE OUTRA FAMÍLIA, OUTRA LIINGUA, OUTRA TERRA
}

\author{
CAROLINA CHAGAS KONDRATIUK \\ Doutoranda \\ Universidade de São Paulo \\ Université Paris 8 Vincennes-Saint-Denis \\ MARCOS GARCIA NEIRA \\ Universidade de São Paulo
}

RESUMO O artigo apresenta os resultados da primeira fase de uma pesquisa que objetiva elucidar os processos educativos informais envolvidos no cuidado profissional doméstico de crianças em contextos migratórios, como estes são vivenciados no plano da corporeidade. Dentro do referencial teórico-metodológico da pesquisa biográfica em educação, constrói-se a partir de narrativas de vida de mulheres brasileiras que atuam ou atuaram como babás na França. Os corpos dessas mulheres, sensiveis à experiência de si, do outro e do mundo, carregam marcas da própria trajetória enquanto se ocupam dos corpos infantis sob seus cuidados. Assim sendo, seus relatos, permeados pela condição corporal, oferecem elementos valiosos para a compreensão de facetas até então inexploradas do cuidado profissional de crianças em ambiente doméstico, quando este é desempenhado num contexto de imersão em diferenças linguísticas, econômicas e socioculturais. A análise, desenvolvida a partir de uma perspectiva hermenêutica, lança luz sobre dinâmicas de aprendizagem implicadas no trabalho de cuidado doméstico de crianças nas quais o corpo é, ao mesmo tempo, receptor e vetor. Por fim, a escuta à sua voz abriu, para as colaboradoras, um espaço de formação de si, um convite a atribuir sentidos à existência e fortalecer a própria atuação no mundo.

Palavras-chave: Corpo. Educação Informal. Migração. História de Vida. 
ABSTRACT BEING A NANNY ON THE OTHER SIDE OF THE

OCEAN: CARING FOR CHILDREN OF ANOTHER FAMILY, ANOTHER LANGUAGE AND ANOTHER LAND

The article presents the results of the first phase of a research that aims to elucidate the informal educational processes involved in professional domestic childcare in migratory contexts, as they are experienced in the corporeality plan. Within the theoretical and methodological framework of biographical research in education, it is based on biographical narratives of Brazilian women who work or worked as nannies in France. These women's bodies, sensitive to the experience of others and of the world, carry marks from their own trajectory while taking care of children's bodies under their responsibility. The narratives, therefore permeated by the corporeal condition, provide valuable insights for the understanding of unexplored facets of childcare work in domestic environment, when it is performed in a context of immersion in linguistic, economic and social-cultural differences. From a hermeneutic perspective, the analysis sheds light on learning dynamics implicated in domestic childcare work, in which body is both vector and receptor. Lastly, the listening to these women's voices opened a space for self-formation, as an invitation to attribute meanings to existence and strengthen their own power to act in the world.

Keywords: Body. Informal Education. Migration. Life History. DE LOS HIJOS DE OTRA FAMÍLIA, OTRA LENGUA, OTRA TIERRA

El artículo presenta los resultados de la primera fase de una investigación que objetiva elucidar los procesos educativos informales involucrados en el cuidado profesional domestico de niños en contextos migratorios, como son experimentados en el plano de la corporeidad. Dentro del marco teórico y metodológico de la investigación biográfica en educación, está basado en narrativas biográficas de mujeres brasileñas que actúan o actuaron como niñeras en Francia. Los cuerpos de esas mujeres, sensibles a la experiencia del otro y del mundo, llevan señales de su propia trayectoria mientras se ocupan de los cuerpos infantiles bajo su responsabilidad. Por lo tanto, sus relatos, impregnados por la condición corporal, ofrecen elementos valiosos para la comprensión de facetas inexploradas del trabajo de cuidado de los niños en entorno doméstico, cuando es realizado en un contexto de inmersión en diferencias lingüísticas, económicas y socioculturales. El análisis, desde una perspectiva hermenéutica, 
arroja luz sobre dinámicas de aprendizaje implicadas en el trabajo de cuidado domestico de niños en las cuales el cuerpo es a la vez vector y receptor. Por fin, la escucha a su voz abrió, para las colaboradoras, un espacio de formación de sí, una invitación para asignar sentidos a la existencia y fortalecer su propio poder de actuar en el mundo.

Palabras clave: Cuerpo. Educación Informal. Migración. Historia de vida.

\section{Introdução}

Este trabalho se debruça sobre a experiência do exercício da função de babá vivida por mulheres em conjunturas de deslocamentos espaciais, linguísticos e culturais. Objetiva elucidar os processos educativos informais envolvidos no cuidado profissional doméstico de crianças em contextos migratórios, como estes são vivenciados no plano da corporeidade. A documentação de narrativas autobiográficas de mulheres brasileiras que trabalham - ou trabalharam, durante algum período da vida como babás na França foi o caminho percorrido. A análise, tecida a partir da palavra dessas mulheres, buscou compreender as dinâmicas de aprendizagem entremeadas pela corporeidade colocadas em marcha nessa ocupação que, neste estudo, recebe destaque em relação a outras categorias do trabalho doméstico. O corpo da babá, corpo educado e corpo educador, desempenha simultaneamente o papel de receptor e vetor de aprendizagens, na medida em que se situa e rediz entre, de um lado, as experiências vividas ao longo de toda a vida e, de outro, a atividade profissional de cuidar de crianças em um contexto sociocultural e linguístico diferente de seu meio de origem.

$\mathrm{Na}$ intimidade de casas de outras pessoas, do outro lado do oceano, essas mulheres se ocupam de cuidar dos filhos de outra família, falantes de outra língua, com raízes em outra terra. A repetição do termo 'outro/outra' aponta para a existência de múltiplas camadas de alteridade e diferenciação, com as quais elas se deparam quando saem de seu país de origem para trabalhar como babás. Diante desse quadro, o artigo parte de uma reflexão, pautada na fenomenologia, sobre o corpo na pesquisa biográfica, intitulada 'ser babá, uma condição corporal'. o corpo é aqui compreendido como lugar de relação com o outro e com o mundo, nó de encontro entre coletivo e individual e, portanto, inevitavelmente presente nas dinâmicas de aprendizagem. Tal abertura oferece os elementos norteadores da análise que segue - melhor designada como interpretação ou leitura, já que esforço hermenêutico -, organizada em torno de três eixos: cuidar dos filhos de outra família, os filhos de outra língua e os filhos de outra terra. Assim, partindo da problemática motriz, a intepretação das narrativas de vida percorre as interfaces entre cuidado profissional de crianças em ambiente doméstico e vivências de aprendizagem e significação resultantes da travessia de fronteiras culturais, linguísticas e espaciais, por meio da compreensão do papel desempenhado pela corporeidade nesses processos.

Antes de explicitarmos os procedimentos metodológicos da pesquisa, é importante localizá-la dentro do quadro mais amplo dos estudos sobre migração e trabalho doméstico. Na contemporaneidade, a tecnologia dos transportes amplia as possibilidades de deslocamento e reduzem-se as distâncias pela 
crescente velocidade. Essa nova conjuntura mundial traz consigo o estabelecimento de interações interculturais de nova natureza e em intensidade sem precedentes. Os movimentos migratórios engendram não apenas encontros entre pessoas, mas também entre os mundos construídos por sua imaginação, perpassada por elementos locais e globais, por imagens sobre o mundo, o Outro, por representações de gênero, nacionalidade etc. 0 emprego de mulheres brasileiras como babás em outros países constitui uma das paisagens fluidas e complexas formadas na atualidade pelo grande número de pessoas em movimento ao redor do globo (APPADURAI, 2004).

Significativo número de mulheres viaja de diferentes partes do globo em direção a países mais ricos. Chegando ao destino, encontram maior facilidade para trabalhar no campo do emprego doméstico que em outras áreas, em especial aquelas que preveem qualificações e formações específicas. Isso ocorre como se, para realizar tarefas ligadas à esfera domiciliar, bastasse ser mulher. Tal é a amplitude do fenômeno que a chamada globalização do trabalho doméstico vem sendo foco de pesquisas com abordagens sociais, históricas e políticas (CHAMOUX, 2004; HOCHSCHILD, 2004; ROMERO, 2013; IBOS, 2012; LAN, 2006). Tais estudos sobre trabalho doméstico e migração, dentre os quais uns tematizam o cuidado doméstico profissional de crianças de forma mais destacada da ampla categoria do trabalho doméstico que outros, oferecem elementos fundamentais para o debate sobre as questões de gênero e o lugar da mulher na contemporaneidade. A perspectiva biográfica permite uma via de entrada diferente e complementar, na medida em que propõe o acesso a conhecimentos produzidos pelos próprios sujeitos a partir de sua existência. No caso desta pesquisa, possibilita aceder aos saberes, reminiscências e significações das próprias mulheres, sujeitos de vivências de deslocamentos geográficos, linguísticos e culturais, a partir de sua experiência de trabalho, como babás, em ambiente doméstico num país estrangeiro. Ao invés de falar sobre os sujeitos ou falar por eles, a pesquisa biográfica dedica-se a ouvir sua voz, numa narrativa que é sempre construída em relação (DELORY-MOMBERGER, 2017).

Por meio da pesquisa biográfica, nos propusemos a ouvir algumas dessas mulheres, de modo a acessar o território de sua subjetividade e de sua experiência pessoal. Ao mesmo tempo que se propõe a devolver para a sociedade saberes construídos em seu interior por alguns de seus atores, sujeitos sociais singulares, tal empreitada desempenha uma função fundamentalmente formativa, pois convida as colaboradoras a dar forma e sentido à sua existência. Cabe salientar que este estudo olha especificamente para a ocupação de babá, levando em conta suas particularidades em relação a trabalhos domésticos de outra natureza. Diferentemente da categorização que abarca babás, faxineiras, cozinheiras etc. sem distinção, consideramos as particularidades desse trabalho que trata essencialmente do estabelecimento de uma relação alicerçada no cuidado e na educação de crianças. Desse modo, o presente estudo insere-se no amplo campo da pesquisa educacional a partir de uma dupla entrada: por seu interesse pela temática praticamente inexplorada dos processos de ensino e aprendizagem envolvidos no cuidado doméstico de crianças e por se interessar pelo processo de biografização dos sujeitos, constituindo a narrativa de si como ferramenta de formação de si.

\section{Procedimentos metodológicos}

No desenvolvimento da investigação, seguimos os referenciais teórico-metodológicos da Pesquisa Biográfica em Educação, confor- 
me fundamentos e práticas propostos por Delory-Momberger (2014) e apoiamo-nos nas contribuições da História Oral, especialmente na forma como foram organizadas por Meihy (1996, 2011). Os relatos orais de mulheres brasileiras que trabalham ou trabalharam como babás na França, construídos de acordo com os caminhos delineados por essas duas perspectivas, apresentam elementos valiosos para a articulação entre experiências vividas e (re) significadas pelo ato de falar sobre si e dinâmicas de aprendizagem informal em contextos complexos.

A história da História Oral está fortemente ligada ao movimento feminista, que encontrou nessa vertente uma potente ferramenta de valorização e legitimação da palavra de mulheres, até então desautorizadas como produtoras de saber (SHARPLESS, 2006). Suas vozes e seus saberes contribuíram para a criação de uma nova história, redefinindo os critérios acerca do que seria historicamente relevante. A busca da História Oral pelo empoderamento de minorias, cuja palavra não é ouvida ou levada em conta no âmbito acadêmico, vem ao encontro de nossa intenção de escuta à voz de babás. Este estudo reafirma a atualidade desse dispositivo excepcionalmente adequado para desvelar aspectos da experiência cotidiana de mulheres. As babás têm sido deixadas à margem no campo da pesquisa educacional, que ainda ensaia os primeiros passos para uma compreensão da dimensão formativa de seu trabalho, realizado no espaço abstruso dos lares.

0 caminho de acesso às colaboradoras mostrou que, em terras distantes e tratando-se do emprego doméstico, as vias oficiais apresentam mais obstáculos que o caminho informal. Por tratar-se de trabalho desenvolvido em ambiente doméstico, a aproximação às profissionais do cuidado de crianças é significativamente dificultada. Diferentemente de profissões formalizadas e institucionali- zadas em organizações como sindicatos, essa ocupação é predominantemente informal. Ao mesmo tempo, na definição de uma porta de entrada a esse universo, o contato com famílias empregadoras foi desde o princípio descartado, uma vez que as relações de poder e o sentimento de proteção à privacidade do lar dificultariam a interlocução. Frente a esse cenário, inicialmente, as agências de babás e as escolas de língua francesa que oferecem cursos especiais voltados a essas profissionais na França pareceram-nos vias de acesso interessantes. Entretanto, o andamento da pesquisa revelou novos empecilhos, pois, desde os primeiros contatos, tais instituições mostraram pouca efetividade no estabelecimento de uma ponte. Este é um dado significativo, que ressalta como, escondido na privacidade dos domicílios, o trabalho doméstico encontra-se em uma espécie de lusco-fusco, ainda insuficientemente conhecido e tematizado. Todavia, abriu-se uma possibilidade paralela extremamente frutífera, sobre a qual passamos a trabalhar.

O contato com brasileiras que vivem em Paris trouxe ao nosso conhecimento a existência de um grupo onde elas se organizam por meio de uma rede social. Em meio ao grande fluxo global de pessoas e de informação, recursos tecnológicos tornam-se uma via fundamental para a manutenção de laços de identificação que extrapolam uma localidade. Noções de pertencimento associadas a etnia, nacionalidade e vizinhança passam, desse modo, por um movimento de desterritorialização (APPADURAI, 2004). Com essa ferramenta, as brasileiras que vivem na França se mantêm vinculadas a elementos que remetem à sua terra natal, compartilhando mundos imaginados, mesmo estando espacialmente distantes delas. O grupo constitui-se uma comunidade virtual de apoio mútuo, tão importante longe de casa, que engloba desde a indicação a va- 
gas de trabalho, o oferecimento de prestação de serviços variados, até a possibilidade de criação de laços de amizade. Uma publicação em tal grupo por parte de uma das integrantes, apresentando sucintamente nossa pesquisa, foi suficiente para que grande quantidade de brasileiras, que trabalham ou trabaIharam como babás na região parisiense, nos procurasse. Ficou evidente a vontade de falar sobre a própria experiência por parte dessas mulheres.

A existência desse desejo de falar sobre si, tendo o anteparo de uma escuta interessada, remete à noção de que ter experiência não significa meramente ter vivido ou passado por. Com base em Dewey (1971), entendemos como experiência aquilo que se constrói por meio de uma narrativa sobre o experimentado e que, através da reflexão, o (re)significa, (re) constrói e articula. Poder falar de si é, nesse sentido, poder agir, pois a narrativa é o espaço mesmo onde o sujeito toma forma, onde ele constrói a si mesmo (DELORY-MOMBERGER; HESS, 2001). Aqui reside seu potencial emancipador, inicialmente descrito nas artes da existência por Foucault (2007) e extensamente desenvolvido, no campo específico da formação de educadores, por autores como Pineau (2006), Nóvoa (1994), Bueno et al. (2006), Passeggi e Câmara (2013). Dispositivos que conduzem o olhar do sujeito para si mesmo the devolvem o poder de refletir sobre a construção de si e de sua vida. Com o convite para contar suas vidas, foi aberto a essas mulheres um espaço para construir-se e reconstruir-se, atribuir sentidos à existência e fortalecer a própria atuação no mundo.

A Pesquisa Biográfica em Educação rompe com a ideia de coleta de dados como finalidade da entrevista biográfica. Não se trata de recolher informações, mas de estabelecer, em interação, um espaço de formação de si e de fortalecimento do poder de agir no mundo.
Em vista disso, o convite a babás para falarem sobre si, realizado no contexto de uma pesquisa acadêmica, bagunça providencialmente lugares instituídos e status atribuídos a cientistas/pedagogos(as) e babás. Tal convite, pelo posicionamento assumido na pesquisa, afirma a pertinência e a relevância dos saberes e experiências dessas mulheres, sujeitos sociais singulares, que não são mero objeto de um estudo, mas colaboradoras em sua construção.

A partir desse grupo inicial, estabelecemos as primeiras conversas, entrevistas informais, nas quais pudemos identificar as colaboradoras com as quais daríamos continuidade à pesquisa. Tendo em vista a problemática norteadora, essa definição obedeceu a critérios qualitativos ligados ao papel que a corporeidade ocupa em seu trabalho. Assim, nos interessamos particularmente por babás que, em sua prática, percebem o corpo infantil como 'algo mais' que um corpo que precisa simplesmente ser alimentado, mantido limpo e seguro até o momento de ser devolvido aos pais. Alice, $\mathrm{Ce}-$ cília e Emília ${ }^{1}$ são profissionais em cuja relação com as crianças sob seus cuidados é notável a percepção de uma singularidade. Elas se distanciam da noção do cuidar como processo anônimo e percebem o corpo infantil como portador de histórias, sensibilidades, emoções e marcas identitárias. Do mesmo modo, endereçam-se a ele, na construção de laços, a partir de sua própria singularidade.

A análise que segue é tecida a partir da palavra dessas três mulheres, convidadas a contar sua história de vida. Os encontros resultaram em mais de 18 horas de narrativas, que foram gravadas, transcritas e encontram-se, atualmente, em fase de transcriação, conforme procedimentos descritos por Meihy (2011). Por meio desse processo, análogo à tradução entre

1 Os nomes das colaboradoras, bem como das crianças e demais pessoas mencionadas nas narrativas, foram modificados para preservar sua identidade. 
línguas, a narrativa oral é vertida em texto escrito buscando expressar os sentidos emitidos, não só pelas palavras, mas também pelos silêncios, entonações, ritmos, expressões faciais e corporais. Como aponta Mazé (2006), não existe consenso entre os historiadores orais sobre se e como deve ser feita a transposição do oral para o escrito. Enquanto alguns defendem a passagem literal dos sons captados pelo gravador para a linguagem escrita, outros encontram na transcriação uma solução para o desafio colocado pelo reconhecimento da existência de significados que excedem o que foi captado pelo gravador e que são veiculados por elementos não verbais, igualmente constitutivos e relevantes do aqui-agora do encontro entre pesquisador(a) e colaborador(a). A busca por uma maneira de transpor o falado para o escrito que seja, ao mesmo tempo, fiel ao momento concreto do diálogo e suficientemente fluida e clara para o leitor assemelha a transcriação a uma arte, mais que a um processo mecânico (PAGE, 2004). Alinhados a esse segundo posicionamento, buscamos a forma escrita que se aproximasse tanto quanto possivel das narrativas orais fascinantes e cheias de vida que se deram em cada encontro.

Trechos das narrativas, particularmente relevantes para a compreensão da interface entre o cuidado profissional de crianças em ambiente doméstico, as vivências de aprendizagem e significação envolvidas na experiência migratória e o papel desempenhado pela corporeidade nesses processos, foram selecionados e analisados, ou interpretados, a partir de uma perspectiva hermenêutica. Podemos falar de três niveis de leitura: o próprio ato de contar, por parte das colaboradoras, é uma primeira leitura. No esforço de biografização, os sujeitos se engajam na tarefa de fazer sentido em cima de fragmentos de memória. Esforçam-se, destarte, em costurá-los na construção de uma narrativa de si. A percepção desse movimento afasta radicalmente a ideia de um pretenso relato objetivo dos fatos, sem, entretanto, perder-se em subjetivismo ou particularismo. Como esclarece Meihy (1996), o que interessa é justamente a experiência subjetiva do que foi vivido coletivamente. Trata-se de uma abordagem centrada na interface entre o individual e o social, segundo a qual o sujeito é entendido como ser social singular (DELORYMOMBERGER, 2014). Se, de um lado, trata de uma dimensão particular e subjetiva, de outro, remete a planos mais amplos da coletividade e da vida social. Toda vivência individual se dá no interior de um espaço social compartiIhado, em um tempo histórico que lhe dá contexto. Evidentemente, esse caráter coletivo e social também se faz presente na dimensão corporal da narrativa biográfica. Bernard (1976) frisa a propriedade relacional da corporeidade, quando nos lembra que o corpo com o qual vivemos não é jamais totalmente nosso. De Certeau (2002), por sua vez, aponta como mesmo nossos modos de vestir, comer, falar, andar etc. são atravessados por construções coletivas. Assim, ao falar sobre suas experiências corporais, essas mulheres se referem a conjuntos de saberes e representações compartilhados.

$\mathrm{Na}$ pesquisa biográfica, a leitura é vista como elemento ativo no processo de significação, logo, um novo nível de interpretação ocorre na tessitura da análise. A partir de um olhar também localizado, propomos uma leitura possível, construída com base no esforço de compreensão dos relatos, do estabelecimento de relações entre entres e deles com a realidade social em que foram gestados. 0 texto escrito, para o qual foram vertidas as narrativas orais, é sempre multidimensional e polifônico. Sendo assim, o produto dessa dupla leitura também será, finalmente, interpretado a partir da ótica de cada leitor, que lhe conferirá nuanças e significações próprias. 


\section{Ser babá, uma condição corporal}

$\mathrm{Na}$ locução 'ser babá do outro lado do oceano', 'ser' refere-se, primeiramente, a uma dimensão corporal da experiência, pois nossa presença no mundo se opera pelo corpo (MARZANO, 2008). Como assinala Le Breton, em La sociologie du corps (1992, p. 3), todas "as ações que tecem a trama da vida cotidiana, desde as mais fúteis ou menos perceptiveis àquelas que se desenrolam na cena pública, implicam o entremeio da corporeidade". ${ }^{2}$

As narrativas biográficas a partir das quais se constitui o presente estudo são, portanto, essencialmente permeadas pela condição corporal. As palavras proferidas em voz alta pelas colaboradoras ao longo das entrevistas e vertidas posteriormente em texto escrito, tecem, em um esforço de biografização, uma história a partir de experiências e memórias que passam por seus corpos e neles se inscrevem. Cada uma dessas mulheres experimenta, elabora e atribui sentido ao trabalho doméstico de cuidado de crianças em um país estrangeiro a partir das cenas vistas, sons e palavras escutados, gostos, cheiros e toques sentidos. Suas narrativas são, portanto, relatos sensiveis, tingidos por marcas que vão da alegria à dor, do toque afetuoso ao estranhamento e rejeição ao outro e/ou pelo outro, do prazer do movimento na brincadeira infantil ao cansaço físico, do confronto com um novo mundo à saudade das relações deixadas para trás.

$\mathrm{Na}$ introdução da coletânea Éprouver le corps, Delory-Momberger (2016) traz importantes elementos para a reflexão sobre o papel da corporeidade na pesquisa biográfica. Apoiando-se na fenomenologia, principalmente nas contribuições de Merleau-Ponty, a autora propicia uma compreensão do corpo como espaço primeiro, sempre presente. Nele, vivemos a experiência de nós mesmos e dos outros em

2 Tradução nossa. meio à trama do mundo, onde tomamos forma. Ela define o corpo como

[...] não um lugar entre outros, mas o lugar onde
se originam todas as experiências e para onde
elas retornam, o fundo original sobre o qual se
constrói a relação sensivel e dinâmica da 'mi-
nha' presença [...] no mundo e frente ao outro,
a 'ancoragem' [...] a partir da qual o mundo se
desdobra para mim e onde 'eu' me desdobro no
mundo. (DELORY-MOMBERGER, 2016, p. 8-9)

Falar sobre ser babá é, portanto, abordar experiências vividas no corpo carne, entendido como trama interconectada com o mundo e com os outros. O termo carne (leibn) é aqui empregado no sentido dado por Husserl (1998) e Levinas (1990), que designa o corpo vivido e sensivel. A expressão corpo carne, em sua concepção fenomenológica, ajuda a superar a oposição entre corpo subjetivo, experimentado 'de dentro' e corpo objetivo, que pode ser estudado 'de fora', compreendido como 'coisa' ou 'conjunto de órgãos' (körper). Desse modo, aponta para uma conciliação entre os polos ter um corpo-objeto ou ser um corpo-sujeito. Se concebêssemos o corpo como o mecanismo descrito pelo discurso das ciências médicas e anatômicas (LE BRETON, 2008), nossa indagação disparadora perderia seu sentido. A questão que motiva esta investigação pressupõe o reconhecimento de que os corpos - das babás, das crianças, dos membros das famílias empregadoras etc. -, longe do pretenso neutro e generalizado que só existe pela mágica operada pelas abstrações, não são meros dados naturais, nem tampouco se reduzem a qualquer espécie de matéria impessoal.

Não existem corpos sem marcas de memória, nem tampouco que não sejam perpassados por usos, códigos e significados compartilhados, tecnologias e políticas que determinam aquilo que deve ser lembrado e o que deve ser esquecido, o que deve ser visto e o que deve

3 Tradução nossa. 
ser escondido, o que deve ser valorizado e o que deve ser adestrado, negado ou corrigido. Lugar de encontro entre o coletivo e o singular, o corpo pertence a populações e a sujeitos únicos, que recriam, reinventam, afirmam, negam, posicionam-se como pertencentes ou desviantes em relação a processos disciplinares e prescrições ligadas a categorizações de gênero, etnia, nacionalidade, geração etc. As narrativas de si não se dão, portanto, de maneira descolada de sua ancoragem corporal. Ao contrário, nas palavras de Santos (2011, p. 39), "a memória parte do corpo, habita o corpo, é corpo".

As narrativas analisadas no presente estudo contam experiências de corpos femininos que receberam marcas, foram educados, cuidados, inseridos em contextos coletivos outorgantes de significado e pertencimento e que, na função de babás, passam a cuidar e educar outros corpos. Em seus primeiros anos de vida, foram também embalados, nutridos, ensinados, colocados em relação, e posteriormente ocupam a posição de fazê-lo em relação a outros corpos infantis. Os corpos infantis confiados aos seus cuidados possuem, outrossim, a particularidade de estarem inseridos em uma realidade em muitos aspectos diferente das condições originais. Com efeito, desempenhar esse trabalho significa estar dentro da casa de uma família, realizando profissionalmente a tarefa de cuidar de suas crianças, em um contexto nada ordinário, pois distante de suas raízes, com inúmeras diferenças do ponto de vista social, econômico, cultural e linguístico. As narrativas desvelam, não simplesmente a experiência de ser babá, corpo educado e corpo educador, mas de sê-lo do outro lado do oceano, com todos os níveis de deslocamento implicados nesse movimento de desterritorialização.

Como veremos, tal quadro nos coloca diante de processos de aprendizagem nos quais o corpo é receptor e vetor. Em sua teorização sobre a transmissão cultural Wulf (2014) e Wulf et al. (2004) salientam o papel central desempenhado pela corporeidade, é por meio de uma aprendizagem ancorada no corpo e nos sentidos que os seres humanos assimilam e recriam as produções materiais e simbólicas das comunidades culturais em que participam. Tal compreensão nos convida a olhar para uma educação difusa, que se opera por meio de palavras, gestos, olhares, espaços, objetos aos quais se atribuem sentidos compartilhados, modos de organização do tempo, formas de alimentação, de higiene, de convívio etc.

\section{Cuidar dos filhos de outra família}

Cuidar de filhos que não são seus, em ambiente doméstico, é um desafio inerente ao ser babá, seja no próprio país ou em terras distantes. Entretanto, quando a via de entrada ao trabalho de guarda das crianças num país estrangeiro se dá pela mediação de uma agência de au pair, ${ }^{4}$ como foi o caso de Emília, outras representações são acessadas, gerando expectativas diferentes daquelas comumente associadas a um trabalho profissional, com relações claras entre empregador e empregado. Ela conta que seu projeto era ir à França para viver uma experiência de intercâmbio cultural, aprender a língua e os costumes locais, sendo acolhida por uma família como 'filha'. Em contrapartida, teria a função de cuidar das crianças como ‘uma irmã mais velha'. Nessa configuração, acreditava que cuidaria dos filhos de pessoas que seriam, também para ela, como pais.

A agência vende muito essa ilusão de que você vai como fazendo parte da família. Então, eles

4 Jeunne fille au pair é o termo usado na França para designar estudantes estrangeiras que, em um período de intercâmbio no país, são acolhidas por uma família, onde ocupam-se das crianças em troca de moradia, alimentação e auxílio financeiro. 
vão te tratar como a irmã mais velha. Você vai ter, sei lá, um cuidado, uma família que te apoia. Acho que foi por isso que escolhi au pair e não qualquer outro intercâmbio. Porque eu vou estar completamente sozinha, mas eu vou ter uma família francesa. Essa era a ilusão mesmo.

No desenrolar de seu relato, Emília pontua inúmeros momentos em que essa expectativa inicial foi frustrada e como ela, gradativamente, precisou ser revista. Aos poucos, os acontecimentos desestabilizavam a representação de ser parte da família, e the sobrepunham a mensagem de que seu corpo tinha que ocupar, na casa, o lugar de empregada. Nem todos os espaços the eram destinados e o uso de seu tempo deveria atender a lógicas diferentes dos demais habitantes da casa. O signo crucial da diferença em relação aos laços familiares reside, em última instância, na percepção de que, em uma relação profissional, desagrados podem gerar uma demissão.

Então, a gente foi numa casa que eles alugaram onde tem os castelos e tudo. Estava toda a família, os outros irmãos do pai, outras crianças e tal. Isso foi, acho que alguns dias antes deles me mandarem embora. Mas, assim, eu estava tentando me sentir bem. Eles iam na piscina, eu ia junto. Eu estava tentando me sentir da família. [...] Então, [a demissão] foi uma coisa superchocante.

- Não, vamos conversar, eu posso melhorar.

- Não, a gente já decidiu, a gente já avisou as crianças.

Aí que eu me dei conta da gravidade: 'Meu Deus, já até contaram!'

- Já avisamos os avós. Avisamos a pessoa da agência e ela vai ligar para você hoje à noite, então, a gente vai deixar o telefone com você mais um dia.

Foi superdificil. À noite, a mulher da agência me ligou. Eu comecei a chorar. Nunca ficava chorando com pessoas estranhas, mas ali era tão... eu não tinha ninguém conhecido! E aí o que que eu faço? Não vou contar pra minha mãe, porque se eu falar isso pra minha mãe, ela vai pedir pra eu voltar na hora.

A vivência de cuidar dos filhos na casa de uma família, sem, no entanto, pertencer a ela, trouxe para Emília dados de uma realidade dolorosa. Morar no mesmo lar, mas tendo uma porta de entrada separada, alimentos separados, não sentar junto aos demais na hora das refeições, não poder ter horários de lazer e de vida social foram algumas das dificuldades encontradas nas primeiras famílias, que levaram à tristeza e ao isolamento. A imagem das 'Cinderelas globais', evocada por Lan (2006) sintetiza de modo bastante expressivo a existência de barreiras de gênero, de diferenças sociais e de desigualdades globais dentro da privacidade de casas, quando estas se tornam local de trabalho de mulheres estrangeiras. 0 emprego de mulheres migrantes para cumprir os afazeres tradicionalmente associados ao feminino com frequência condiciona a liberação de uma mulher, para trabalhar fora ou dedicar-se a outras atividades, à opressão de outra. No corpo de Emília, o sofrimento materializou-se num expressivo aumento de peso, realimentando ainda mais o processo de tristeza e isolamento social, num ciclo vicioso. Aos poucos, inscreviam-se em seu corpo signos de novas identidades e diferenças, distantes daquelas vividas na terra natal.

Além disso, tal quadro provocou um afastamento da própria família, já que compartilhar as dificuldades enfrentadas com sua mãe acarretaria uma reação de proteção que colocaria fim ao projeto de vida traçado por Emília, quando decidiu morar na França. Ela não tinha intenção de voltar sem ter realizado aquilo a que se havia proposto. Segundo Sahoui (2017), no projeto migratório se entrecruzam as expectativas individuais daquele que empreende a viagem e as da família que fica no país de origem. Uma dimensão coletiva se soma ao projeto migratório pessoal. Para 
Emília, recorrer à família brasileira sem antes conseguir ser bem-sucedida equivaleria a desistir de seu plano de crescimento. Com efeito, nos anos seguintes, ela conheceu outras configurações de trabalho que the ajudaram a se estabelecer no país.

Em muitos momentos, mais que cuidar dos filhos de outra família, de modo geral, ser babá significa cuidar dos filhos, especificamente, de outra mulher. Nas narrativas de Alice, Cecília e Emília é notável como as atribuições junto à criança e ao gerenciamento do trabalho da babá recaem majoritariamente sobre a mãe empregadora, sendo menor, porém não inexistente, a participação masculina nessas dinâmicas. Essa assimetria de papéis nos casais também foi observada por lbos (2012), em seu estudo sobre as relações entre babás marfinenses e seus empregadores franceses. Tal quadro evidencia como o ambiente privado é atravessado por lógicas culturais que diferenciam não só o homem da mulher, mas também as duas mulheres entre si. Muitas dificuldades decorrem dessa condição, ganhando roupagens a depender da combinação única que se dá no encontro de duas mulheres: mãe e babá. Longe de mostrar estagnação diante delas, as narrativas revelam a mobilização de estratégias para a resolução de problemas e soluções criativas possibilitadas justamente por condições adversas e contextos desestabilizadores de modelos prévios. As babás, com seu repertório e inventividade, desempenham papel ativo na elaboração de significados enquanto se dedicam aos afazeres de cuidado dos pequenos, em aprendizagens que necessariamente passam pelo corpo. Nas etnopaisagens do trabalho de brasileiras em casas francesas há um riquíssimo encontro de imagens sobre si, sobre o Outro e sobre o mundo, geradoras de tensões, evidentemente, mas também de trocas.

Quando as crianças sob seus cuidados não são suas, a alimentação é uma das primeiras questões que se colocam. Montagem do cardápio, escolha dos ingredientes e modo de preparo são ações fundamentadas em um conjunto de representações bastante próprios de cada grupo. Na família em que trabalha, Alice se deparou com uma geladeira repleta de alimentos congelados, algo bastante diferente do ambiente em que foi criada:

A minha primeira dúvida era pra fazer o jantar. Quando eu cheguei nessa casa vi que todos os alimentos eram congelados. Todos, todos, mesmo os legumes. Então, isso pra mim foi um choque! Como alguém pode comer bem, comendo alimentos congelados? Mas ela [a patroa] me disse:

- Você sempre pode preparar o que você quiser.

Então, eu pensei: 'Como a minha mãe faria?' Aí eu sempre tento escolher coisas que são saudáveis, tento fazer coisas naturais. Eles comem de tudo! Eu posso fazer coisas bem brasileiras, com alho e cebola, que essas crianças não reclamam.

A pergunta 'Como minha mãe faria?' foi a estratégia adotada por Alice, uma mulher sem filhos, como forma de recorrer à própria bagagem diante dessa e de inúmeras outras situações cotidianas em que deveria decidir como agir com as crianças. Camufladas na pequenez do cotidiano, as artes de fazer (DE CERTEAU, 2002) materializam relações dinâmicas entre modos de agir prescritos e esperados e aqueles que caracterizam pequenas resistências, apropriações e releituras. É assim que as invenções do cotidiano devolvem aos sujeitos, em dinâmicas de negociação constante, a possibilidade de escapar à simples conformação passiva. No percurso de Alice, os modos de fazer ocasionam, eventualmente, alguns desencontros entre os sistemas de representação em jogo e demandam novas adaptações.

Eu sempre tomo café. Um dia, eu estava tomando café e o Hugo foi chegando:

- Eu posso tomar um pouco? 
Eu achei normal, porque eu tomo café desde pequena. Minha mãe fazia pra mim mamadeira de café com leite! E eu dei um pouquinho de café pra eles. Dei pra o pequenininho, depois o grande quis também, eu dei também. Aí o Charles comemorou como se tivesse feito a coisa mais radical do mundo:

- Nooossa, essa noite eu vou contar pros meus pais que você me deu café!

Eu engasguei:

- Por quê? Você não pode tomar café? Criança aqui não toma café?

- Não, não. Só uma vez que eu experimentei o vinho do meu pai e, agora, eu experimentei café com você.

Nossa, então foi o equivalente a uma bebida alcóolica! Meu Deus! Eu fiquei com medo.

- Então vai ser o nosso segredo, tá bom? Você não conta para sua mãe que você tomou café.

- Tá, então não vou contar.

Ele não contou e eu também não dei mais.

As crianças não são impermeáveis aos hábitos do adulto que cuida delas, observando atentamente e aprendendo com suas formas de ser, falar e agir. Em algumas oportunidades, diferenças nos modos de fazer ordinários geram novas aberturas e o convívio íntimo acaba por propiciar a transmissão de saberes e valores. Wulf (2014) observa que essa espécie de transmissão se dá por processos miméticos cuja lógica obedece à ideia de modelo, e não de simples cópia. Não se trata de transmissão unilateral, mas de uma aprendizagem motivada pelo desejo da criança de parecer-se com o adulto, como forma de fazer parte dos processos culturais da sociedade em que vive, combinando criação e imitação. Isso significa que, nas aprendizagens assim perpetradas, as crianças exercem papel ativo para ressignificar e recontextualizar elementos trazidos pela babá estrangeira. Certa vez, quando escovava os dentes depois de comer, Alice, que era observada atentamente por Charles, foi questionada:

- Mas por que que você escova os dentes agora?

- Porque, no meu país, a gente escova os dentes quando a gente se levanta e, em todas as refeições, a gente escova os dentes.

Aí ele ficou curioso:

- Mas e quando você não tá em casa?

- A minha escova fica na minha bolsa.

- É? A sua escova fica na sua bolsa?! Aqui a gente só escova o dente antes de dormir! - Ele ficou superespantado.

E quando a mãe chega muito tarde, ela pede pra que eu escove os dentes das crianças e que eu comece a preparar pra dormir, fazer brincadeiras mais tranquilas... Só que ele não gosta muito.

- Não, eu quero fazer com a minha mãe!

- Então eu vou escovar o dente com você.

Aí ele fica olhando como eu escovo os dentes... e quer fazer igual. Ele entra na brincadeira e faz. Nisso, eu ensinei que quando a gente escova o dente, a gente tem que colocar água na boca e jogar água fora. Ele disse:

- Não, não é assim que minha mãe faz, é de outro jeito! É só a pasta de dente que limpa os dentes.

Mas aí ele começou a fazer assim comigo. No outro dia, ele vai lá e conta pra mãe. E ela fala:

- Você pode fazer como você quiser. Se você quiser fazer como a Alice, você faz.

Agora ele faz como eu ensinei.

Tais experiências mostram como, com frequência, o encontro com o novo vai além de simples curiosidade, que se contenta com a constatação de diferenças, e ocorre de as crianças incorporarem novidades aprendidas com a babá em seu próprio repertório. Nas situações de alimentação e higiene citadas, dentre ou- 
tras presentes nas narrativas, o encontro de corpos materializa o encontro de mundos. As noções de higiene e do que seria o corpo 'puro' ou 'limpo' variam de um grupo para o outro, de uma época para a outra, do mesmo modo que as noções de saudável ou prejudicial. Os julgamentos de bom ou mal aplicados em cada área da vida cotidiana, como higiene, alimentação e saúde, obedecem a lógicas diferentes, que modelam não somente os corpos que a elas obedecem, mas também sua sensibilidade (VIGARELLO et al, 2008). Em cada época e cultura, dispositivos deslocam os limiares da vergonha e da repulsa recriando socialmente o que é considerado distintivo ou civilizado. Assim, determinam sentimentos como o de repulsa, pautados num dado julgamento do que seria sujo, repugnante ou indigno, mas que são tomados como naturais por quem os experimenta. Nesse encontro de mundos, a casa é palco de apropriações em múltiplas direções. Se, por um lado, Hugo e Charles passaram a cuidar dos dentes como Alice, ela passou a tomar vitamina D para enfrentar os efeitos do inverno, como o pediatra havia receitado aos meninos.

Estas e outras experiências narradas abrem novas perspectivas a partir das quais podem ser vistas as paisagens do cuidado doméstico de crianças por mulheres migrantes, pois o banho, a alimentação, o brincar, a troca de roupas e a hora de dormir, entre outros momentos da interação cotidiana entre criança e babá, se configuram como situações de troca e aprendizagem. Longe de serem anódinas, as experiências que se inscrevem nos corpos, dando-lhes forma e sentido ao longo de toda a vida - incluindo aquelas mais habituais e corriqueiras, que para olhos desatentos poderiam ser consideradas banais, - fazem parte de processos formativos. De acordo com Soares (2004), o corpo é objeto de uma educação polissêmica, é texto em escrita constante, lugar onde se materializam códigos, práticas, compreensões e valores da coletividade em que se insere. "Os corpos são educados por toda a realidade que os circunda, por todas as coisas com as quais convivem, pelas relações que se estabelecem em espaços definidos e delimitados por atos de conhecimento" (SOARES, 2004, p. 120).

A grande receptividade dos pequenos à bagagem cultural da babá foi igualmente sinalizada por Brites (2007), em seu estudo sobre o trabalho doméstico em lares brasileiros. A autora nota que tal abertura ocorre mesmo nos casos em que os pais mantêm uma postura de fechamento frente ao universo da empregada doméstica. Evidentemente, houve um favorecimento decorrente da postura receptiva adotada pela patroa de Alice. Tal abertura, entretanto, não elimina as tensões inerentes ao papel ambíguo de cuidar das crianças e, ao mesmo tempo, ser uma funcionária dentro da casa.

Eu já percebi que algumas das vezes que a mãe quer falar alguma coisa que não está boa no meu trabalho, ela fala pras crianças. Por exemplo, um dia eu deixei a geladeira da casa aberta. E como não é um lugar que eles vão frequentemente, estragou um pouco de comida. Ficou um dia aberto. Aí o mais velho me disse no outro dia:

- Ah, minha mãe pediu pra você olhar se você fechou a geladeira, porque ela teve que jogar um montão de comida fora!

É... Num outro dia, também, a moça que limpa a casa quebrou uma coisinha da pia e o pai criou um grupo no WhatsApp, eu, ele e a moça da limpeza, e perguntou quem tinha quebrado. Eu disse que não fui eu. Ela disse que não foi ela. $E$ aí, num outro dia, o Charles perguntou pra mim:

- Você tira isso todo dia pra lavar a louça?

Então eu imagino que foi o pai que tinha falado com ele.

Cuidar dos filhos de outra mulher, quando esta é a patroa, e não alguém da família, uma amiga ou vizinha, traz particularidades importantes, já que remete a uma hierarquização 
com base em marcadores que extrapolam a questão geracional. Esses e outros episódios narrados por Alice evidenciam a fragilidade da fronteira entre ser um adulto com autoridade em relação à criança e ser empregada da família. São momentos em que o menino se posiciona ocupando o papel de patrão. Isso ocorre como se, em algumas situações, o status de filho da patroa autorizasse a misturar ou inverter as relações entre criança e adulto. As diferenças de atributos entre o que é ser um ou outro ficam nebulosas e outra categorização se sobrepõe ao critério etário. Categorias identitárias das quais o corpo é suporte se interpõem e alternam no estabelecimento das relações com a criança cuidada. Quando isto ocorre em detrimento da autoridade da babá, opera-se uma didática da distância social. Outros estudos sobre o trabalho doméstico (BRITES, 2007; ROMERO, 2013; COROSSACZ, 2014; LAN, 2006) já abordaram essa temática, denunciando modos pelos quais algumas casas se transformam em ambiente socializador que naturaliza a desigualdade, trazendo para dentro de suas paredes uma estratificação pautada em categorias de gênero, classe, cor e etnia.

As narrativas trazem paisagens complexas, nas quais diferentes repertórios são mobilizados diante de situações desafiadoras. Cecília, outra colaboradora do estudo, também conta que as memórias do jeito de educar de seus pais estão bastante presentes em sua prática com Dan. Diferentemente do que ocorria com Alice, que formulava explicitamente a pergunta sobre como sua mãe faria, essa relação não se dava de maneira consciente, mas veio à tona durante a tessitura da narrativa.

Meus pais sempre foram muito brincalhões. Então, eu acho que, se eu tenho um lado mais engraçado, de às vezes fazer uma piada ou alguma coisa assim, isso vem deles. Com certeza, isso reflete, hoje em dia, em algumas coisas do meu jeito. Que nem agora, trabalhando como nounou, ${ }^{5}$ eu vejo que eu organizo jogos com as crianças todas do prédio, né? Porque é um prédio que tem um pátio embaixo, então é ótimo! $E$ isso é uma coisa que remete aos meus pais, assim, de pegar todas as crianças da vizinhança e propor:

\section{- Ah, vamos fazer um jogo de vôlei!}

E montar a rede e fazer o tal do jogo. Uma coisa que eles não se preocupavam era com a bagunça de receber as crianças! Eles organizavam esses momentos e tinham bastante disposição.

Além de identificar influências da própria experiência de infância em seu jeito de atuar com as crianças, a narrativa de Cecília revela o conflito que vive diante do desafio de encontrar, na condição de babá, formas de intervir adequadas. Ela aponta a existência de muitas diferenças em relação à atividade profissional que desempenhava no Brasil. Como psicóloga, diz ter construído a experiência de atender crianças no ambiente da clínica, onde tinha uma postura muito mais receptiva e observadora, totalmente diferente de ser babá e ter ela mesma que agir no dia a dia da casa. Os limites para essa ação estão dados, o tempo todo, pelo fato de ser a criança de outra família.

Um dia ele brincou com o skate duma vizinha, era uma sexta-feira e ele disse:

- Ai, eu queria um skate! Eu queria um skate!

- Ah, né, vamos ver, talvez um dia tu tenha. - Eu fui conversando com ele. - Mas tu pode usar o da tua amiga, ela te empresta.

Ele ficou uns 40 minutos brincando com o skate da menina. Na segunda-feira, quando eu cheguei na casa dele, já tinha um skate. Então ele é um menino que eles não deixam ficar no desejo. Tudo que ele deseja, ele já tem a resposta logo. É bem da modernidade. Assim ele está sempre com desejo, né? Sempre com um desejo novo. E aí eu disse:

5 Babá. 
- Ué, um skate?!?

- Ai, eu ganhei esse skate...

- Nossa, que legal! Nossa, mas tu tem muita sorte! Tu sabe que tu tem muita sorte de já ter ganhado esse skate? Eu achei que tu ia ter que esperar atééé o Papai Noel... - daí eu comecei a fazer umas historinhas assim, pra ver se ele dá pelo menos um pouco de conta pra valorizar, né? E ele:

- É, né? Eu tenho sorte...

Ele não teve tempo pra isso. Nossa, era muito diferente na minha infância! Eu esperava o Natal, acho que por isso que eu falei no Papai Noel, né? Porque eu esperava o Natal e era, assim, o dia mais maravilhoso do mundo! Acordava no dia 25 e estavam aqueles presentes que o Papai Noel tinha ido de noite e a gente nem escutou, sabe? Então, eu penso na riqueza disso, de ficar esperando e de no outro dia acordar e ficar imaginando que o Papai Noel veio, deixou o que a gente queria e daí ficar curtindo muito aquele presente durante muito tempo. Porque o skate dele agora já está abandonado, né?

Essa passagem mostra, claramente, a diferença nas bagagens pessoais da babá e da mãe, em termos de valores, de projeto de formação para a criança e até mesmo de repertório de estratégias para manejar a educação dada a ela. Porém, é interessante observar como Cecília não fica paralisada diante desses contrastes. Ao contrário, ela encontra maneiras de estabelecer um diálogo com a mãe, de modo respeitoso e, muitas vezes, bastante sutil, mas que abrem uma via para que ela possa reavaliar algumas posturas. No caso do skate, por exemplo, ela conseguiu ajudar a mãe de Dan a perceber melhor a dinâmica de satisfação imediata que estava sendo criada.

Eu sei que na segunda feira ele foi andar com o skate. Quando a mãe dele chegou, a gente estava no pátio ainda brincando, aí ela veio conversar comigo, animada:

- Ai, tu viu que ele ganhou o skate?
- Sim, superlegal! - Daí eu disse - Ai, eu fico impressionada como ele é coordenado, né? Imagina, de sexta... Sexta-feira foi a primeira vez que ele andou de skate e olha como ele já está andando em pé agora! - Ele já estava até conseguindo virar assim com o skate, sabe?

Ela ficou espantada:

- Mas ele andou de skate sexta-feira?!?

- Sim, a Anne emprestou pra ele e ele ficou um tempão aqui no pátio brincando. Ainda, eu fui pegando na mão dele pra ajudar.

- Ele me falou que ele não andou, por isso que...

Enfim, ela percebeu que ele usou a história como se tivesse passado muita vontade. Coitadinho, né? Todo mundo tem skate e ele não. Ele quer muito e não pode andar...

Com o tempo, o olhar de Cecília vai sendo reconhecido e valorizado na dinâmica familiar, de modo que, em seu papel de babá, vai se estabelecendo uma parceria com a mãe. Além de oferecer novos dados à patroa, intervenções diretas com o menino mostram como Cecília, de forma bastante cuidadosa, encontrou uma via para caminhar nesse terreno delicado de cuidar do filho de outra mulher dentro de sua própria casa. Sua atuação com Dan se dá sem negar nem invadir o espaço da mãe, sem desautorizá-la, mas, ainda sim, abrindo para ele um outro ponto de vista.

Depois eu falei com ele também, né?

- Ai, eu fiquei um pouco pensando, né? Que tua mãe disse que tu falou pra ela que tu não tinha andado de skate e tu andou. Lembra que a gente andou juntos?

Daí, ele dá uma risadinha um pouco sem graça.

- Mas por que será que tu precisou falar isso?

Vou conversando assim pra tentar ajudar ele. Eu acho que tá ajudando um pouco, sabe?

Contando como, ao cuidar, a babá também educa, Cecília contribui para a desconstrução da cisão entre cuidar e educar, tão recorrente 
nos discursos sobre esse trabalho doméstico. Os trechos das narrativas acima expostos colocam imediatamente em questão a representação bastante difundida - e que provavelmente toma parte no silêncio sobre as babás no campo da Educação - de que a babá 'só cuida' da criança, sem participar de sua educação, que ficaria a cargo de outras instâncias como a família e a escola. Mas a inserção de uma mulher brasileira atuando como babá no seio de uma família francesa ainda traz consigo os efeitos da desterritorialização de um elemento fundamental na constituição das interações: a língua.

\section{Os filhos de outra língua}

Quando babá e criança falam línguas diferentes, a constituição da relação entre ambas passa por caminhos, muitas vezes, pouco usuais. As diferenças linguísticas, inerentes ao contexto do trabalho de cuidar de crianças em casas de família em um país estrangeiro, trazem à tona, nas narrativas das colaboradoras, diversos obstáculos originados dessa situação. Nas trajetórias de todas elas, é marcante a presença de caminhos pelos quais se constituem os laços de afetividade e autoridade, estratégias criativas que possibilitam a comunicação cotidiana, formas não verbais de linguagem que podem ser mobilizadas na troca de significados e experiências.

Na relação entre babá e criança, diferentes tipos de linguagem não verbal são mobilizados, como os gestos, a mímica, as entonações da voz. A expressividade do corpo foi decisiva na experiência de Cecília. Ela conta que, no dia da entrevista para conseguir o trabalho, terminou a conversa certa de que não seria contratada, pois nem os horários ela havia conseguido entender sem que Marine, a mãe de Dan, os escrevesse num papel. Após a conversa, Marine propôs a Cecília que ficasse meia hora com o menino. Nessa ocasião, a linguagem do corpo desempenhou papel central e a ligação entre os dois se estabeleceu pelo jogo de futebol. Depois do relato feliz do menino para a mãe, Cecília foi contratada apesar da barreira da língua.

Frequentemente o caráter abstrato e cognitivo da linguagem nos faz esquecer que a corporeidade é central também na fala. Articulação, entonação, emissão envolvem a participação orquestrada de músculos, órgãos e sistemas do corpo. Mesmo tendo um bom domínio do francês, por estudos realizados ainda no Brasil, Emília vivenciou dificuldades no estabelecimento de vínculos de afeto e de autoridade na relação com as crianças. Ela conta, por exemplo, que as crianças de uma das famílias em que trabalhou zombavam de sua pronúncia, dizendo que ela não estava dizendo merci (obrigado), mas sim Messi (o jogador de futebol). A voz é emanação corporal que existe sempre em relação (LE BRETON, 2011). A tessitura da voz e sua qualidade, para além das palavras, é suficiente para gerar situações de estranhamento frente ao outro, quando sua voz é categorizada como estranha, diferente, fora da norma. Em outras ocasiões, Emília experimentou obstáculos de compreensão da língua viva, com suas nuanças e especificidades nos usos de cada grupo e região.

No início, você não consegue muito se comunicar. Eu não sei nem como as pessoas vêm sem estudar nada, porque tem muita gente que vem sem estudar, sabe? Só sabe falar abajour e bonjour. E eu que tinha estudado e tudo, mas eles falam mais rápido, têm a linguagem familiar, é complicado pra entender as palavras... Então, sempre tinha uma certa confusão. A forma de se vestir era diferente e até o nome que eles davam pra roupa, não sei se é porque eles eram do norte, se é porque eram da campagne, ${ }^{6}$ mas era assim. Tinha um tal de maillot que não era o maillot de banho... A única família em que eu ouvi falar isso foi essa. Era maillot de corps, que

6 Campo. 
era tipo a camiseta pra pôr antes de tudo. E na hora de ajudar as crianças a se vestir eu ficava perdida:

- Maillot de corps?! o que que é isso?

Tarefas básicas tornam-se quase intransponíveis pela falta de domínio do código próprio àquele contexto. Para Emília, as dificuldades nesse quesito localizavam-se na pronúncia e no domínio de vocabulário específico. Todavia, como ela mesma pondera em seu relato, muitas mulheres chegam com dificuldades mais importantes. Foi o caso de Alice. Ela, que só tinha acompanhado uma vez a babá antiga, a quem substituiu, no momento de buscar os meninos na escola, viveu uma grande provação no primeiro dia sozinha:

No primeiro dia em que fui buscar na escola, eu fiquei completamente perdida com as crianças. Eu não sabia o endereço da casa e não conseguia ligar pros pais e perguntar, porque a gente não conseguia se comunicar muito bem. Nossa, eu fiquei um tempão andando com as crianças! Eles ficaram muito cansados! Falavam, mas eu não entendia. Até que eles tocaram numa casa e pediram pra dona pra fazer xixi. Só aí que fui descobrir o que era que eles estavam pedindo, porque eu nem sabia como era pedir pra fazer xixi em francês. Nada, nada, nada, nada.

A incompreensão absoluta foi dando espaço a interações cada vez mais complexas. No início, Alice usava desenhos. Ao mesmo tempo, aprendia a língua local com as crianças, a imersão no país e as aulas de francês.

Com essas primeiras crianças foi um desafio, porque eu não falava nada de francês, tinha três meses que eu estava aqui. Eu não falava nada e eles já tinham uma babá brasileira, mas também não entendiam muito. Primeiro dia eu já pensei: 'O que que eu vou fazer pra conseguir realizar o meu trabalho?' Então eu criei desenhos. Foi a primeira coisa que eu fiz. Eu sabia que as minhas obrigações iniciais eram: pegar na escola, dar banho, fazer jantar, colocar o mais velho pra fazer o dever, mas ele faria sozi- nho, e depois brincar com as crianças até a hora que os pais chegassem. Então eu fui fazendo os desenhos. Eu desenhava a atividade e o número que ia aparecer no relógio. Na hora, chamava eles e mostrava. E aí com o tempo, eles foram me ensinando a falar. Eu aprendi o básico e aí fui conversando, brincando e aprendendo mais.

O desenho funcionou para Alice, Charles e Hugo, como código compartilhado, pedra de roseta para aproximar dois mundos. Ela conta que, aos poucos, os pequenos também aprenderam um pouco de português. Algumas palavras habituais e músicas foram incorporadas ao cotidiano da casa, restrito ao círculo formado pelos três. Foi o caso, por exemplo, de uma música infantil brasileira que passou a marcar a hora do banho, nomeando as partes do corpo. Palavras como orelha, testa, coxa e pé foram assim incorporadas ao vocabulário dos dois francesinhos. A desterritorialização da língua, da etnia, da noção de pertencimento, fez com que esses elementos se espalhassem através das fronteiras nacionais, criando situações como essas, em que vemos, também no âmbito da linguagem, as casas se tornarem palco de aprendizagens interculturais. Essas aprendizagens, vivenciadas por adultos e crianças e ancoradas no corpo, se desenrolam entre jogos, mímicas e desenhos. Quando a voz, esse "fino filete de sentido mesclado de sopro"7 (LE BRETON, 2011, p. 217) entra em cena, as aprendizagens estendem-se, ainda, para os domínios da língua francesa e da língua portuguesa. Cabe agora olhar para como as mulheres agentes desses processos, habitantes de um lugar longe de suas raízes, experienciam em seu corpo a condição da vida em deslocamento.

\section{Os filhos de outra terra}

Foram aviões que transportaram os corpos femininos de Alice, Cecília e Emília em direção às

7 Tradução nossa. 
famílias cujos rebentos lhes seriam confiados. Poltronas minúsculas, espaço milimetricamente delimitado, comida duvidosa, efeitos da cabine pressurizada e do oxigênio rarefeito são algumas das experiências corporais do trajeto. Em suas Notas sobre o peso e a velocidade dos corpos, Sant'Anna (2001) reflete acerca de alguns dos impactos sobre a experiência humana provocados pela incorporação do trem, do automóvel e, mais tarde, do avião à paisagem natural. Por um lado, olhares positivos viram tais inovações como favorecedoras de uma espécie de libertação do homem em relação à sua geografia e sua história, constatando a inegável ampliação de horizontes e possibilidades. Por outro, críticas denunciaram uma operação de abstração do caminho percorrido. A tentativa de traçar uma trajetória que se aproxima o máximo possível da linha reta, em busca da rapidez ótima na passagem de um ponto a outro, faz desaparecerem paisagens. A eficiência do deslocamento pretere as experiências sensoriais no espaço. Se o viajante consegue olhar por uma das pequenas janelas - o que nem sempre é possivel no apertado ambiente das poltronas e telas - a terra é vista do alto como uma maquete de pequenas linhas e pontos.

No destino, os efeitos do percurso se somam às impressões da chegada em um ambiente desconhecido, como conta Emília:

Quando eu saí do avião ali no Charles de Gaule [...] Eu nunca tinha ido sozinha pra outro país. Já viajei várias vezes, mas nunca sozinha. E eu não conseguia falar direito, acho que por medo. É muito medo, no início. E aí depois de passar na polícia ainda fiquei em dúvida... 'Será que ainda tem outra polícia?' Porque eles só olharam se tinha visto e tchau. Mas eu achava que ia ter um controle de fazer mil perguntas e tal [...] Depois tem que pegar as malas, mas onde que é? Sempre acontece isso comigo aqui, ainda hoje. Qual esteira você tem que pegar a mala? Aí você espera um tempão e... 'Ai essa aqui não era, era a outra!' Aí, você fica vendo aqueles números, sem saber [...] 'Mas é pra qual lado?' Eu tentava falar com as pessoas e ninguém muito que ajudava. Então, todo esse negócio do avião foi muito tenso. E a minha mala ainda veio com uma rodinha quebrada, então, ia toda torta. A maior mala, porque eu vim com duas. E eu superatrasada: 'Meu Deus, vai que a família não vai mais estar lá, vai que foram embora!'. Mas quando eu cheguei estavam as crianças com a plaquinha escrito 'Emi'. Eles ficaram felizes, aí fomos no carro, a gente parou num lugar pra comer e tal. Quando chegamos na casa o pai até falou:

- Ah, você pode dormir tranquila, você deve estar cansada.

Realmente, no dia seguinte eu fui acordar era umas 3 da tarde!

$\mathrm{O}$ acolhimento deu-se pela família encontrada por intermédio da agência, porém, a sensação de familiaridade mostrou, mais tarde, grande fragilidade e foi sendo suplantada por marcadores de diferença e pela delimitação de seu espaço como funcionária. A experiência corporal de estar longe de casa passa também pela necessidade de carregar as próprias coisas consigo. Roupas e objetos necessários à manutenção do corpo precisam ficar como anexos, acompanhando a condição de nomadismo. Cada vez que saía de uma família, nas experiências que não deram certo, a vivência de Emília era marcada pela mala.

Eu fui fazer minha mala e guardei tudo. Eu lembro da sensação que, quando eu fiz a minha mala no Brasil pra vir, era aquela mala grande e tal, mas eu pensava: 'Não, eu tô fazendo essa mala, mas vai ser fazer agora e só vou fazer de novo daqui um ano.'

Era muito assim, só daqui um ano que eu vou ter que guardar tudo de novo, mas ali foram três semanas e eu já fazia a mala. E tantas outras vezes que eu tive que fazer de novo! E minha mala com a rodinha quebrada...

Com o medo de estar sozinha em terra estranha, sem conhecidos, sem ter para onde 
voltar, já que o emprego era também a moradia, a cada demissão Emília via-se de novo desamparada: sem celular, sem computador, sem conhecer a cidade, sem saber como seria a próxima família... A bagagem aparece nessas passagens da narrativa como único algo realmente seu, até encontrar o próximo pouso. Quando ela era despedida, somava-se a toda essa angústia a dificuldade material de transportar as malas durante o intervalo até a próxima casa. Bagagem pesada e dificil de carregar, lembrando o tempo todo que não se é de lá.

[...] Era essa coisa dos prédios antigos de Paris. Tem uma parte que tem aquele elevador dourado, cheio de espelhos, todo bonito, com aquele apartamento de um andar inteiro e aí eles têm acesso com elevador pra todos os andares e tal. E na parte da chambre de bonne $e^{8}$ é a escadinha de empregada, redondinha, estreitinha. E, assim, pra ir até lá, quando eu cheguei, eu estava com a mala quebrada, todo mundo me ajudando e tal. A gente entrou pela parte do elevador, eu fui pelo apartamento e de lá era tipo um andar só ou dois de escadinha. E todo mundo estava me ajudando e tudo. Eles foram queridos nos primeiros dias. [...] Pra ir embora, foi a mala mais rápida que eu fiz na vida, porque eu não sabia quanto tempo ia levar pra eu descer com tudo aquilo sozinha. E eu com um monte de roupas pra aguentar o frio de outubro/novembro: camisa de gola alta, aí outra camisa de lã grossa, outra blusa de lã, mais um casaco. Essa mãe até tinha me dado um casaco de lã dela, bem bonito, que ela não usava mais, comprou outro e me deu. E eu, agasalhada daquele jeito, tinha que descer com todas as malas. 'Meu Deus, vou suar tudo!' Aí eu desci com a primeira mala pequenininha e o casaco e pensei: 'Se alguém roubar, já era, vai ficar aqui mesmo'. Trouxe todas as malas suando. Eram seis andares pela escadinha da au pair. Eu desci cada mala de uma vez. Eu descia alguns degraus, daí tinha que virar a mala assim, porque não cabia o ângulo e aquele peso... Às vezes, eu tentava ir meio que deslizando, só que se soltava demais

8 Quarto de empregada. o troço caía. Nossa, era uma coisa tão louca que eu ficava: 'Não posso pensar, não posso pensar', cansada e o braço estourado, 'não posso parar pra pensar nada agora, não posso chorar.' Eu estava anestesiada.

Momentos como esse revelam a fragilidade da condição de deslocamento daquele que vive no entrelugar, que habita uma terra sem realmente fazer parte dela. Lugar da experiência, da relação consigo e com o mundo, o corpo carrega o peso e a leveza de uma casa que não se fixa mais em um espaço definido, da condição de não ter para onde voltar, da incerteza e da liberdade de uma vida em movimento. A permanência no novo país depende de um conjunto de fatores. Mesmo quando se tem um visto para morar e trabalhar, existem outros papéis importantes na constituição de uma vida em outra terra. Cecília é formada em Psicologia e atendia num consultório em sua cidade natal, mas ir para a França significou recuar grandes passos nesse percurso.

Semana passada, eu recebi a resposta que o meu diploma não foi validado. Só vai ser validado quando eu acabar o mémoir. ${ }^{9}$ Com o master ${ }^{10}$ a minha graduação em Psicologia passa a ser reconhecida, só que eu tenho Especialização no Brasil, eu estudei nove anos lá. O master, o mémoir são nulos perto dos trabalhos que eu fiz lá. Sábado foi o dia que eu peguei a correspondência, foi um dia triste. Foi um dia de 'puta merda', sabe? Eu entendo, deve ser superdificil validar diploma de fora, a partir de papéis ali que tu olha, né? Mas o que me deixou mais assim é que a gente tá sempre nas mãos de algum outro. Outro que vai te dar a resposta se tu tá bem aqui, se tu não tá bem, se tu tá legal, se tu não tá legal, se tu tem papel, se tu não tem papel. Foi dificil de receber a resposta. Eu tive que ir no Correio pegar e fui pruma praça pra abrir. Quando eu abri o papel, já comecei a chorar. Tinha umas pessoas ao meu redor e ficaram me olhando. E eu: 'Ai, meu Deus do céu, que vergonha, mas enfim... rale-se! Preciso chorar!'

9 Trabalho de conclusão de Mestrado.

10 Mestrado. 
Em sua história, Cecília fala da angústia de sentir-se nas mãos de um outro, a quem cabe legitimar e validar, o tempo todo, quem ela é e que lugar ocupa. No próprio país, onde cada um nasce e cresce, esse processo vai sendo construído ao longo de toda a vida, de modo que, em dado momento, certas conquistas estão consolidadas e não precisam mais ser provadas. Na ausência de reconhecimento de sua formação, o trabalho de babá foi a opção acessivel escolhida, entre outras como ser vendedora ou garçonete, para ser desempenhada enquanto seu diploma não era validado. Cecilia fala dessa escolha como algo positivo, enxergando nela uma preparação para atuar futuramente como psicóloga no país, uma vez que propicia a imersão numa realidade cultural tão diferente da sua. Dentro das casas em que trabalha, como babá de Dan e como baby sitter de três irmãos que habitam no mesmo condomínio, ela pode conhecer, de dentro, o ambiente familiar francês, tendo uma experiência intensa com seus hábitos e costumes, que dificilmente seria adquirida de outro modo.

Ao longo da construção de suas narrativas de si, as colaboradoras refletem sobre os próprios percursos e se envolvem num esforço de interpretação e elaboração de significados para o experienciado como babás em terras francesas. Fica saliente, nessas reflexões, a presença de uma figura de liberdade nos projetos pessoais de morar fora do país. Nas palavras de Emília:

Sempre morei com minha mãe, tinha minha vida segura. E aí, você está num outro país, você não sabe nada, não tem ninguém pra te dizer o que fazer. É ótimo, porque você é totalmente livre e é também muito interessante porque você perde totalmente todas as suas referências. É uma insegurança, dá um medo, mas ao mesmo tempo dá uma liberdade, porque aí você pode fazer e criar quem você quer ser de novo.
Orientadas por essa ideia de liberdade, Alice, Cecília e Emília significam o trabalho de babá como etapa constitutiva de um caminho com objetivos maiores. A estada dessas mulheres como babás em lares franceses faz parte de um projeto pessoal de crescimento, e não de uma realidade imposta pela luta pela sobrevivência. Nossas colaboradoras desempenham o trabalho doméstico como ocupação-ponte e não ocupação-gueto, conforme a categorização proposta por Romero (2013). Essa distinção permite localizar se esse tipo de trabalho, socialmente pouco valorizado e malremunerado, ocupa um papel transitório ou definitivo na vida de quem o executa. Nos três casos, elas encontraram barreiras transitórias para entrar em outros setores melhor remunerados, executando o serviço doméstico como etapa de um caminho traçado com perspectivas de crescimento.

Tal figura de liberdade, norteadora das histórias dessas mulheres, também encontra formas de expressão no plano da corporeidade. Na narrativa de Alice, sua experiência aparece materializada, de forma marcante, no percurso do trato com os cabelos.

Aqui eu posso sair do jeito que eu quero! Lá todo mundo ficava falando que eu tinha que alisar o cabelo, que não era bonito cabelo enrolado... Eu alisei meu cabelo a vida toda. Desde 9 anos minha mãe alisa meu cabelo. [...] Ela passava o pente com aquela força toda e doía, amarrava, assim, puxando bem repuxado. Aí ela me levou no salão e pediu pra alisar. Eu lembro que era um produto com um cheiro bem ruim mesmo, horrível. Eu não gostava do meu cabelo liso, mas eu tinha que aceitar aquele cabelo porque era o cabelo que minha mãe queria. Eu preferia ele natural, mas pra ela o meu cabelo assim era juba de leão, ela falava. Na escola também, quando eu tentava deixar meu cabelo natural sempre tinha alguém falando:

- Ah, mas não é muito padrão, você tem que fazer chapinha pra ficar bonita. 
Quando eu vim pra França, eu ainda fiz a progressiva e cheguei com o cabelo liso. Um dia, eu decidi: 'Não quero mais.' Aí eu fui, cortei meu cabelo mais curto do que ele está hoje e falei 'agora eu quero meu cabelo natural.' Me aceito do jeito que eu sou, saio com a roupa que eu quero. Não fico mais me preocupando. E o que as pessoas falam aqui é totalmente o contrário do Brasil. Todo mundo acha bonito, acham diferente. Porque é uma coisa que normalmente não tem aqui.

Ao lado do que Alice exprimiu em palavras, um dos momentos de entrevista foi ocasião de um episódio bastante expressivo. Estávamos numa pracinha, aonde ela leva os meninos nos dias de sol. Charles e Hugo brincavam de colocar flores amarelas e soprar sementes brancas nos cabelos de Alice, cujos cachos ficaram cobertos pelos adornos improvisados. Todos riam e se divertiam. Sem querer ou saber, eles ilustraram e agregaram vida a uma trajetória de ressignificação do cabelo como marca identitária da mulher brasileira.

\section{Considerações finais}

O fluxo de pessoas ao redor do globo acontece, na atualidade, em escala e intensidade sem precedentes. Nesse contexto, as casas de outros se tornam, com frequência, locais de trabalho para mulheres migrantes, muitas delas encarregadas do cuidado das crianças. Elas vivenciam experiências migratórias entre a amplitude da vida num país estrangeiro e a intimidade da vida particular dentro do ambiente doméstico. Neste estudo, colocamos em relevo o trabalho de babá em sua especificidade, pois ao mesmo tempo que se aproxima dos demais campos profissionais relativos às tarefas domésticas por aspectos como a (des)valorização social e econômica, o trespassamento por tensões relativas a representações de gênero, classe e etnia, a ausência de regulamentação das relações profissionais, entre outros, dis- tingue-se deles pela centralidade da relação adulto-criança na caracterização de sua natureza. Nessa relação, a questão dos processos educativos se impõe de maneira incisiva: que aprendizagens se dão em ambientes domésticos que empregam uma mulher estrangeira para atuar no cuidado das crianças?

As narrativas de Emília, Alice e Cecília revelam que cuidar dos filhos de outras famílias no interior das casas onde vivem significa participar de sua educação. Ao trazer esses elementos, o conjunto das narrativas indica a necessidade de superação da visão que tenta separar cuidado de educação na definição da função da babá. Entretanto, as narrativas também mostram que as aprendizagens informais vivenciadas nesses contextos não se limitam à experiência da criança, mas se estendem a todos os sujeitos envolvidos nas interações. Trata-se de aprendizagens, vivenciadas por adultos e crianças, que encontram ancoragem no corpo, passando, portanto, pelos sentidos e pela mimesis.

Nas palavras de nossas colaboradoras, a experiência migratória confere colorações particulares ao exercício da função de babá. Tais narrativas elaboram experiências encarnadas, no sentido de serem vividas no corpo carne, que têm lugar em uma situação bastante particular: por meio delas verteu-se em palavras a experiência de cuidar de filhos que não são seus, em uma língua diferente da sua, com raízes em uma terra distante de suas próprias origens. O desafio de cuidar de filhos de outra família, inerente à tarefa da babá, ganha novas roupagens quando vivido em um país estrangeiro. Os relatos de Alice, Cecília e Emília mostram situações de conflito geradas pelo fato de uma outra mulher, mãe da criança, ser alguém de outra cultura, alguém com quem os laços não são familiares, mas sim profissionais, alguém com bagagens e visões de mundo diferentes. Interessantemente, tais confrontos 
são expostos como propiciadores de desestabilização de modelos prévios, busca criativa de soluções e desenvolvimento de novas configurações possiveis. Compondo mais um plano de alteridade, temos o mergulho numa língua estrangeira no contexto íntimo das casas de família. Cuidar dos filhos de outra língua origina novos obstáculos, que por sua vez motivam a busca de caminhos alternativos para o estabelecimento de laços de afetividade e autoridade, de estratégias inovadoras para a comunicação cotidiana.

A presença de babás brasileiras em lares franceses compõe, destarte, paisagens extremamente ricas em interações interculturais. Nas interações entre babá, criança e família, se educa e se aprende em processos nos quais o corpo é vetor e receptor. Se, de um lado, podemos identificar aprendizagens ocultas ou subliminares, como aquelas inscritas no plano de uma didática da distância social, por meio das quais são marcados lugares e significados distintos aos corpos que habitam/trabalham na casa, outras espécies de aprendizagem se interpõem. Formas de agir, de se cuidar, se alimentar, se vestir e ver o mundo fazem circular noções de higiene, alimentação, beleza e saúde que moldam tanto os corpos como as sensibilidades. Modos de fazer camuflados na pequenez do dia a dia trazem à tona o aspecto criativo e abrem aos sujeitos a possibilidade de pequenas resistências na invenção do cotidiano. No plano das trocas linguísticas, a babá aprende com as crianças e vice-versa, no amplo leque de linguagens corporais que vão do gesto à emissão da voz, do jogo de futebol ao vocabulário da língua portuguesa, do desenho com giz de cera à pronúncia parisiense.

A entrada nesse universo pela via da pesquisa biográfica possibilita o acesso a saberes e experiências vivenciados por sujeitos sociais cuja voz tem sido deixada à margem. No jogo do poder cultural, grupos dominantes elabo- ram e divulgam representações pretensamente universais. Qualquer representação pertencente às culturas alheias, caso se distinga da cultura dominante, receberá menor carga valorativa. A representação do outro constituise por uma mínima seleção de características presentes, cujo objetivo é apenas lidar com sua presença na esfera pública, sem conhecê -lo de fato, sem ter de enfrentar um contato mais intenso e conhecer seus pormenores, sutilezas etc. Trata-se de uma visão estática que submete o outro à cultura autora da representação. É nesse jogo que os grupos que detêm o poder simbólico de definir o que é válido afirmam para si a condição de identidade, de normal, de padrão a ser seguido, representando o outro como o diferente, algo a ser corrigido ou deixado à margem das decisões sociais (NEIRA; NUNES, 2009).

0 ato de dar a palavra às protagonistas desse universo vai, portanto, na contramão daquelas manifestações culturais que divulgam uma identidade cultural como superior, cujas narrativas submetem o outro à condição de inferior, bárbaro ou primitivo. A pesquisa autobiográfica destaca não só os conhecimentos e as práticas sociais dos grupos dominados, em especial, mulheres, negros e povos da América Latina, como também suas histórias de luta. Valoriza e reconhece a diversidade identitária da população e proporciona o ambiente necessário para que as narrativas de todos sejam efetuadas com base na própria cultura, de forma a relatar suas condições, dificuldades, estratégias de resistência e superação.

Finalmente, é importante considerar a dimensão formativa da própria pesquisa biográfica levada a cabo com mulheres brasileiras, babás na França. Frente ao perceptivel desejo de falar sobre e compartilhar suas vidas, a escuta proporcionou um espaço de construção e reconstrução de si, respondendo a uma busca de sentidos para a existência e de um 
sentimento de poder agir. Falando sobre si, essas mulheres puderam compartilhar as soluções criativas elaboradas, face aos problemas vivenciados em seu corpo-carne. Puderam, ainda, significar o trabalho de babá na França como etapa de crescimento e de busca por liberdade. Por fim, puderam desconstruir e enfraquecer as noções que historicamente menosprezam o papel do trabalho doméstico, mostrando como, longe de se limitar a um trabalho meramente braçal ou mecânico, ser babá exige competências em nada inferiores àquelas ligadas a ocupações social e economicamente mais valorizadas. Sem a pretensão de esgotar o tema, nosso estudo abre a possibilidade de férteis desenvolvimentos no campo da pesquisa educacional, uma vez que a dimensão formativa do trabalho doméstico de cuidado de crianças não é suficientemente reconhecida, nem tampouco explorada.

\section{Referências}

APPADURAI, Arjun. Disjuncture and difference in the global culture economy. In: LECHNER, Frank J.; BOLI, John. (Orgs.). The Globalization Reader. 2. ed. Malden, Oxford, Victoria: Blackwell, 2004.

ATELY-VOL, Marie-Willye. Corps Tout-Monde. Paris: Téraèdre, 2017.

BERNARD, Michel. Le corps. Paris: Jean-Pierre Delange, 1976.

BRITES, Jurema. Afeto e desigualdade: gênero, geração e classe entre empregadas domésticas e seus empregadores. Cadernos Pagu, Campinas, Núcleo de Estudos de Gênero Pagu, n. 29, p. 91-109, jul./ dez. 2007. Disponivel em: <http://www.scielo.br/ $\mathrm{pdf/cpa/n29/a05n29.pdf>}$. Acesso em: 17 mai. 2017.

BUENO, B. et al. Histórias de vida e autobiografias na formação de professores e profissão docente (Brasil, 1985-2003). Revista Educação e Pesquisa, São Paulo, Faculdade de Educação da Universidade de São Paulo, v. 32, n. 2, p. 385-410, mai./ago. 2006.

CHAMOUX, A. F. (Org.). Domestic service and the formation of european identity: understanding the globalization of domestic work, 16th-21st centuries. Bern: Peter Lang, 2004.

COROSSACZ, Valeria Ribeiro. Relatos de branquitude entre um grupo de homens brancos do Rio de Janeiro. Revista Crítica de Ciências Sociais, Coimbra, Centro de Estudos Sociais da Universidade de Coimbra, n. 105, p. 43-64, 2014.

DE Certeau, M. A invenção do cotidiano, artes de fazer. V. 1. 7. ed. Petrópolis, RJ: Vozes, 2002.

DELORY-MOMBERGER, Christine. De la recherche biographique em éducation: fondements, méthodes, pratiques. Paris: Téraèdre, 2014.

(Org.). Éprouver le corps: corps appris, corps apprenant. Paris: Érès, 2016.

Aula ministrada no curso Questions theoriques/Questions de recherche, na Maison des Sciences de l'Homme da Université Paris 13 Sorbonne Paris Cité, 2017.

; HESS, Remi. Le sens de l'histoire: moments d'une biographie. Paris: Economica, 2001.

DEWEY, John. Vida e educação. São Paulo: Melhoramentos, 1971.

FOUCAULT, Michel. História da sexualidade V. II: 0 uso dos prazeres. 12. ed. Rio de Janeiro: Graal, 2007.

HOCHSCHILD, A. R. Le nouvel or du monde. Nouvelles questions féministes, Lausanne, Suisse, Antipodes, 23(3), p. 59-74, 2004.

HUSSERL, Edmund. Méditations cartésiennes: introduction à la phenomenologie. Paris: Vrin, 1998.

IBOS, Catherine. Qui gardera nos enfants? Les nounous et les mères. Paris: Flammarion, 2012.

LAN, Pei-Chia. Global Cinderellas: migrant domestics and newly rich employers in Taiwan. Durham, London: Duke University Press, 2006.

LE BRETON, David. La sociologie du corps. Paris: PUF, 1992.

La chair à vif: de la leçon d'anatomie aux greffes d'organes. Paris: Éditions Métailié, 2008. 
Éclats de voix: une anthropologie des voix. Paris: Éditions Métailié, 2011.

LEVINAS, Emmanuel. Autrement qu'être ou au-delà de l'essence. Paris: Le Livre de Poche, 1990.

MARZANO, Michela. (Org.). Dictionnaire du corps. Paris: PUF, 2013.

MARZANO, Michela. Penser le corps. Paris: PUF, 2008.

MAZÉ, Elinor A. The uneasy page: transcribing and editing Oral History. In: CHARLTON, Thomas L. et al. (Orgs.). Handbook of Oral History. Lanhan: Altamira Press, 2006. p. 237-273.

MEIHY, José Carlos Sebe Bom. Manual de história oral. 5. ed. São Paulo: Loyola, 1996.

MEIHY, José Carlos Sebe Bom; HOLANDA, Fabiola. História oral: como fazer como pensar. 2. ed. São Paulo: Editora Contexto, 2011.

NEIRA, Marcos Garcia; NUNES, Mário Luiz Ferrari. Educação Física, currículo e cultura. São Paulo: Phorte, 2009.

NÓVOA, A. Relação escola - sociedade: novas respostas para um velho problema. In: SERBINO, R. V. et al. (Orgs.). Formação de professores. São Paulo: UNESP, 1994. p. 19-40.

PAGE, S. El participante invisible: el papel del transcriptor. Revista História Oral, São Paulo, Núcleo de Estudos em História Oral, v. 7, n. 1, p. 61-75, 2004.

PASSEGGI, M. C.; CÂMARA, S. C. X. Memorial autobiográfico: uma tradição acadêmica no Brasil. In: SOUZA, E. C.; PASSEGGI, M. C.; VICENTINI, P. P. (Orgs.). Pesquisa (auto)biográfica: narrativas de si e formação. Curitiba: CRV, 2013. p. 29-47.

PINEAU, G. As histórias de vida em formação: gênese de uma pesquisa-ação-formação existencial. Revista Educação e Pesquisa, São Paulo, Faculdade de Educação da Universidade de São Paulo, v. 32, n. 2, p. 329-343, mai./ago. 2006.

ROMERO, M. Nanny Diaries and Other Stories:
Immigrant Women's Labor in the Social Reproduction of American Families. Revista de Estudios Sociales, Bogotá, Universidad de Los Andes, Facultad de Ciencias Sociales, n. 45, p. 186-197, jan. 2013. Disponível em: http://www. scielo.org.co/scielo.php?script=sci_arttext\&pi$\mathrm{d}=\mathrm{S} 0123-885 \times 2013000100015 \& \operatorname{lng}=e n \& \mathrm{nrm}=$ isso $>$. Acesso em: 28 mar. 2017.

SAHOUI, Sofiane. Mesa redonda Acuellir, être acueilli, organizada por Le sujet dans la Cité, Paris, no 27e Salon de la Revue, nov. 2017.

SANT'ANNA, Denise Bernuzzi de. Corpos de passagem: ensaios sobre a subjetividade contemporânea. São Paulo: Estação Liberdade, 2001.

SANTOS, Andrea Paula dos. Corporeidades, oralidades e discursos de memórias frente às tecnologias de informação e comunicação. Revista Oralidades, São Paulo, Núcleo de Estudos em História Oral, Universidade de São Paulo, ano 5, n. 10, p. 31-52, jul./ dez. 2011.

SOARES, Carmen Lucia. Corpo, conhecimento e educação: notas esparsas. In: SOARES, Carmen Lucia. (Org.). Corpo e história. 2. ed. Campinas, SP: Autores Associados, 2004. p. 109-129.

SHARPLESS, Rebecca. The history of Oral History. In: CHARLTON, Thomas L. et al. Handbook of Oral History. Lanhan: Altamira Press, 2006. p. 19-42.

VIGARELLO, Georges et. al. Prefácio à história do corpo. In: História do corpo: da Renascença às Luzes. 2. ed. Petrópolis, RJ: Vozes, 2008. p. 7-14.

WULF, Christoph. Mimesis et apprentissage culturel. Le Télémaque, Presses Universitaires de Caen, n. 15, p.123-136, jun. 2014.

et al. Penser les pratiques sociales comme

rituels: ethnographie et genèses de communauté. Paris: L'Harmattan, 2004.

Recebido em: 30.11.2017 Aprovado em: 25.07.2018 
Carolina Chagas Kondratiuk é doutoranda no Programa de Pós-Graduação em Educação da Faculdade de Educação da Universidade de São Paulo/Université Paris 8 Vincennes-Saint-Denis, Laboratório CIRCEFT (Centre Interuniversitaire de Recherche “Culture, Éducation, Formation, Travail”). e-mail: ckondratiuk@usp.br

FEUSP Av. da Universidade, 308 - Cep.: 05508-040 Cidade Universitária - São Paulo/SP, Brasil. Telefone: (11) 99297-1254

Marcos Garcia Neira é Doutor em Educação. Professor Titular da Faculdade de Educação da Universidade de São Paulo. Líder do Grupo de Pesquisas em Educação Física Escolar (GEPEF). e-mail: mgneira@usp.br

FEUSP: Av. da Universidade, 308 - Cep.: 05508-040 Cidade Universitária - São Paulo/SP, Brasil. Telefone: (11) 98132-1182 